\title{
THE VALENTINE'S CARD IN THE OPERATING ROOM: CODES OF ETHICS AND THE FAILING IDEALS OF THE LEGAL PROFESSION
}

\section{GAVIN MACKENZIE*}

This article discusses the growing disillusionment with the legal profession shared by both lawyers and non-lawyers. This trend is coincident with an evolution of codes of conduct, from those reflecting ethical aspirations to those that spell out legally enforceable minimum standards. The author summarizes some of the contributing factors of this disillusionment. They are the increasing commercialism of practice, the fragmentation of the profession, rampant specialization and the excesses of the adversary system. The author attempts 10 answer the question, "Can modern codes of conduct effectively serve both ideological and regulatory functions?" by analyzing the reasons for disillusionment with the profession, the evolution of such codes and by making proposals for the future.
Cet article parle d'un désillusionnement grandissant à l'égard du barreau, partagé à la fois par les avocats et par le grand public. Cette tendance coincide avec l'évolution des codes de conduite, de ceux qui reflétaient les aspirations èthiques da ceux qui énoncent des critères de discipline ayant force exécutoire. L'auteur résume certains des facteurs qui contribuent à ce sentiment - la commercialisation croissante de la pratique. la fragmentation de la profession, les spécialisations galopantes et les excès d'un système accusatoire. L'auteur se demande si les codes de conduites modernes peuvent remplir efficacement des fonctions idéologiques et réglementaires, en analysant les causes de cette crise, l'évolution des codes et en proposant des solutions pour l'avenir.

\section{TABLE OF CONTENTS}

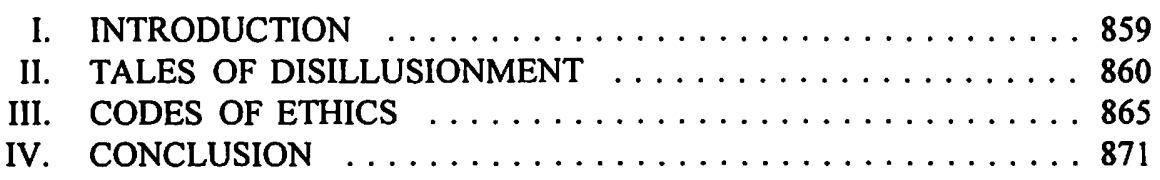

\section{INTRODUCTION}

Professor Anthony Amsterdam once said that the American Bar Association's canons of ethics are of as much use to a lawyer in court as a Valentine's card would be to a heart surgeon in the operating room.'

Largely because of such well-founded concerns about the practical value in an increasingly diverse society of a simple list of ideals to which lawyers aspire, law societies and bar associations in Canada and the United States have promulgated progressively more detailed codes of professional conduct. Some of the provisions of these modern codes bear a greater resemblance to those of comprehensive regulatory statutes than past canons of ethics. At least one commentator has even suggested that the profession's traditional name for the subject-matter of codes of conduct is obsolete: 
If we are not talking about right and wrong, but simply what regulatory rules apply, for policy reasons, in particular legal situations, is there any reason to still refer to this branch of legal thought as "ethics?" Will anything be lost if we call it something else, and simply regulate without the moral overtones? ${ }^{2}$

This evolution of codes of conduct - from those that emphasize collective ethical aspirations to those that spell out in detail legally enforceable minimum standards has occurred at a time of growing disillusionment with the profession. This sense of disillusionment is shared by lawyers and non-lawyers alike.

The reasons for disillusionment are complex: the increasing commercialism of practice, the fragmentation of the profession, rampant specialization, and the excesses of the adversary system are among the contributing factors. We will examine these below.

The publication of codes of ethics has been one way in which the profession traditionally has promoted the view that the practice of law is more than just a business. Modern codes that de-emphasize the profession's ideological aspirations thus may tend to fuel disillusionment. Yet codes that fail to provide practitioners, who are confronted with real and immediate professional responsibility problems, with either sufficient guidance to enable them to resolve the competing interests or specific notice of the kinds of conduct for which they may be disciplined, may ultimately bring even more discredit upon the profession.

Can modern codes of conduct effectively serve both ideological and regulatory functions? To attempt at least a tentative answer to this question, we will examine in turn the main reasons for the present sense of disillusionment with the profession and the evolution of codes of conduct before venturing a few tentative suggestions about the direction in which codes of conduct might be steered in the future.

\section{TALES OF DISILLUSIONMENT}

Legal periodicals published during the last few years abound with stories of lawyers who despair for the profession. ${ }^{3}$ In the last year alone at least two books have been devoted to the decline of professionalism among lawyers. ${ }^{4}$

Two recurring themes pervade these accounts. The first is the chasm between the realities of law practice today and the idealism that attracted many students to the profession; the second is the chasm between those realities and the way in which law was practiced by previous generations of lawyers.

$2 \quad$ M.H. Aultman, "Cracking Codes" (1994) 7 Geo. J. Legal Ethics 735 at 737.

3 See e.g. M. Otvos, "Why I'm Leaving Law" (1992) 16:1 Can. Law. 12-16; M. Orey, "Misery" (1993) American Lawyer 5; Anonymous, "A Litigator's Lament" (1993) American Lawyer 79; L. Greenhouse, "At the Bar: A Pillar of the Law Laments that a 'Noble Profession' Has Become Just Another Business" [New York] Times (8 April 1994) B7; K. Lyskowski, "Conflicted Liberals and the Lure of Money" The National Law Journal (1994) A19.

$4 \quad$ See A.T. Kronman, The Lost Lawyer: Failing Ideals of the Legal Profession (Cambridge: Harvard University Press, 1993); S.M. Linowitz, The Betrayed Profession (New York: Scribners, 1994). 
Surveys disclose that practicing lawyers have the highest job dissatisfaction rate of any major professional group. ${ }^{5}$ This dissatisfaction is not the result of lower than expected standards of living; lawyers are generally well paid, compared to other occupational groups. "We do not worry about subsistence or the survival of our children," wrote one lawyer, before elaborating on the reasons for his dissatisfaction. "In a tough world, we are blessed."6

But though the dissatisfaction of lawyers has little to do with their standard of living, it has much to do with their quality of life. The long hours that are expected (if not required) of practicing lawyers contribute to their perennial difficulty in balancing their professional and personal lives, but are less significant than the nature of the work to which those long hours are devoted. Wesley Williams, Jr., a fifty-year-old partner at a leading Washington firm and the President of the Harvard Law School Alumni Association, complains about fourteen-hour days that start with stacks of computergenerated draft accounts to review; that continue with phone calls from clients haggling over the cost of photocopying; preparing for "beauty contests"; meetings with partners to discuss write-downs, associates, and money; and that end with dinners that double as client pitches. "If any of my children ends up going into the practice of law," he concludes, "I will consider myself to have been defeated."

It is not only the business dimension of law practice that breeds dissatisfaction. The complex transactions and litigation of our time often require dozens of hours of mindnumbing due diligence or document production. ${ }^{8}$ Clients increasingly seek warriors to litigate disputes, and many lawyers allow such client expectations to govern their conduct. "I have personally witnessed otherwise sensible, highly compensated adult attorneys," writes an American litigation lawyer, "fighting ... about whether a lawyer screaming during a deposition was or was not standing up while doing so, and about the crucial distinction between 'hollering' and 'raising my voice'."'

This is not what most students envision when they choose a career in the law. Students may be motivated to become lawyers for many different reasons, including perceived opportunities to attain positions of status and power, or to advance their political ideals. Some of these motivations are more commendable than others. Most students also hope, however, that their work as lawyers will be a source of satisfaction in itself. Professor Anthony Kronman of Yale Law School, in his book The Lost Lawyer: Failing Ideals of the Legal Profession, writes that "the professional pride of lawyers as a group has always depended on the belief that what they do has the potential to be rewarding in this way." 10 
Professor Kronman observes that the "case method" of teaching law reinforces students' idealistic expectations that a career in the law will enable them to derive personal satisfaction from their work by serving the public good. It does so, he writes, by assigning a priority to the judicial point of view, thereby encouraging a civic-minded devotion to the good of the law as a whole."

He adds that earlier generations of lawyers realized intrinsic satisfaction from their work in a way that may be unachievable today. They did so, he writes, by conceiving their highest goal to be the attainment of practical wisdom: "a wisdom that lies beyond technique - a wisdom about human beings and their tangled affairs that anyone who wishes to provide real deliberative counsel must possess." ${ }^{12}$

Professor Kronman nevertheless concludes that there is a growing sense among lawyers generally "that their yearning to be engaged in some life-long endeavour that has value in its own right can no longer be satisfied in their professional work." ${ }^{13} \mathrm{An}$ anonymous litigation lawyer, similarly, writes that "the prototypical legal career can be fairly summarized as a steady enforced drift from the ideals that drew us to this of all vocations." $^{14}$

Why is this so? Professor Kronman ascribes the prevailing sense of disillusionment principally to three "institutional and intellectual forces that are now arrayed" against the traditional ideal, and which together have caused its decline. ${ }^{15}$ First, the currently dominant movements in legal thought - the law and economics and critical legal studies movement - are less hospitable than were their predecessors to the shared attitudes and expectations of lawyers of earlier generations. ${ }^{16}$ Second, the bureaucratization of the courts - the process whereby the work of judges increasingly consists of reviewing decisions made by growing staffs of law clerks - has resulted in a less deliberative and less independent system of administering justice that "has transformed the ancient art of judging into a species of office management whose main virtue is efficiency rather than wisdom."17 Finally, Professor Kronman writes, the way in which law is practiced today, particularly in large law firms, has created an openly commercial culture in which traditional professional ideals have only a marginal place. $^{18}$

My own view is that, at least in Canada, this third reason constitutes by far the most plausible explanation for the prevailing disenchantment of lawyers with their profession. Whatever movements in legal thought law students are exposed to, they seem no less likely than their counterparts of twenty years ago to be lured to the practice of law by

Ibid. at 158-59.

Ibid. at 2.

Ibid. at 3.

Anonymous, supra note 3 at 79 .

Supra note 4 at 4.

lbid. at 4, 166-68, 315 .

Ibid. at 4, 323-31.

lbid. at 4. 
their conviction that to be a lawyer will be gratifying and fulfilling. While the bureaucratization of the courts is a phenomenon we must be on guard against, it has evidently evolved more cautiously in Canada and, in my view, is not a significant explanation for the present state of disillusionment with the legal profession in Canada.

Professor Kronman's account of the changes over the last fifteen to twenty years of the way in which law is practiced provides a more compelling explanation. Corporate clients with in-house law departments are more inclined to shop around for legal services. Law firms have responded by specializing in fields which it does not pay corporations to master because the fields are highly technical and present legal problems that any given organization is likely to encounter only infrequently, such as mergers and complex litigation.

Because clients do more work in-house, and retain different firms to handle different specialized problems, lawyers' clientele tends to be more fluid and relations with individual clients and client representatives less continuous. Client contact is often restricted to extraordinary events that demand a form of highly specialized legal knowledge.

The kind of advice that clients seek and lawyers provide thus tends to be both more episodic and more specialized. The advice is more technical and less deliberative, because deliberative advice requires familiarity with a client and a breadth of understanding of its current situation that is frequently lacking today. Moreover, Professor Kronman writes, practical wisdom is a trait that can be acquired only by making decisions that demand it. The less frequent the occasions on which such decisions are required, the less likely lawyers are to acquire the trait. ${ }^{19}$

The attenuation of the external bonds that tied clients to law firms a generation ago has been accompanied by a similar attenuation of the internal bonds that linked the members of firms to one another. A consequence of the realignment of the client-law firm relationship has been a shift in clients' allegiance from the firm to individual lawyers. Lawyers find it easier today to change firms and to take their practices with them. They are likely to be recruited by other firms: a phenomenon that was considered quite inappropriate a generation ago. Even the pronounced increase in the size of law firms has unavoidably made it harder for lawyers to identify in a personal way with the firms to which they belong. A weakening of client loyalty has been paralleled by a weakening of law firms' institutional solidarity. ${ }^{20}$

The last twenty years or so have also been characterized by an openness about marketing and compensation, which has spawned a preoccupation with money that cannot help but influence the attitudes of young lawyers. Such openly commercial practices as the employment of directors of marketing were non-existent even in the United States as recently as 1980 . Young lawyers are more likely today than formerly to be encouraged to equate success with hours billed and to choose as role models 
business-getters and deal makers rather than the good examples of the past, whom Kronman calls "lawyer-statesmen." "The classical figure of the lawyer statesman has in my generation become a quaint antique with little of the power it once possessed to inspire or excite," Professor Kronman writes. "In the culture of today's law firm, the lawyer-statesman is an anachronistic ornament, and those just entering the culture are encouraged to look elsewhere for their models of success." 21

The consequences of this are varied and significant. The idea of a career in private practice interrupted by periods of public service will inevitably be viewed as unattractive if the point of practicing law is perceived to be the making of as much money as possible; even at its highest levels, financial compensation in public service is almost certain to be lower than that of lawyers in private practice, particularly in mid-career. ${ }^{22}$ More importantly, as Justice Frank Iacobucci has pointed out, women and men who would place their professional values before amassing large profits ultimately will not be attracted to the profession at all if they perceive it to be a business much like any other. ${ }^{23}$

Clients' relationships with lawyers have also changed. Clients today are more likely to micromanage their counsel; in the words of the anonymous litigation lawyer mentioned above, "where once lawyers gave clients perspective, now clients give lawyers marching orders."124 And, where once clients sought lawyers or firms of stature, reputation and credibility, "increasingly, clients give their litigation work to screamers."25 The profession tends to be less congenial and less collegial than it once was. The notion of a wise and independent bar, the anonymous litigator concludes, is left for discussion among academics. The social value of quality lawyering is diminished: "hardworking, quality, ethical lawyers feel professionally impotent and frustrated."126

Little need be said of the modern public's disenchantment with the legal profession. Largely for reasons already alluded to - the preoccupation with money in an openly commercial culture, the weakening of traditional bonds of loyalty, the decline of the wise and independent bar - in the eyes of many members of the public, the legal profession is a self-interested elite. In MacDonald Estate v. Martin, Cory J. wrote of "lawyers soldiering on in the cause of justice. ${ }^{127}$ But to how many members of the public are the lawyers patriots rather than mercenaries?

Ibid. at 13, 280, 286-89, 302 .

Ibid. at 296-97.

Justice F. Iacobucci, "The Practice of Law: Business and Professionalism" (1991) 49 Advocate 859. See also Justice lacobucci's 1992 address, "Striking a Balance: Trying to Find the Happy and Good Life Within and Beyond the Legal Profession" (1992) 25:3 Law Soc. Gaz. 205; and S. Rosner, "Professionalism and Money" (1992) 78 ABA J. 69, 70.

Anonymous, supra note 3 at 81 .

Ibid. at $80-81$.

Ibid.

[1990] 3 S.C.R. 1235 at 1270 [hereinafter MacDonald Estate]. 
Professor Kronman reminds us of the importance of not romanticizing the profession's past. The profession has had its shameful aspects, including perhaps most notably its racial, religious and sexual exclusivity. At the same time, he adds, prior generations of lawyers had an ideal that provided "a foundation on which a sense of professional identity might be built. And because the foundation it provided was rich in human values, this ideal was appealing at a personal level, too." Today, the decline of the ideal has thrown the professional identity of lawyers into doubt. The result, Kronman concludes, is "a collective identity crisis of immense proportions." 28

\section{CODES OF ETHICS}

Codes of ethics can be expected to play only a limited role in influencing lawyers' attitudes and behaviour, and can be expected to play a role that is even less significant in enhancing public confidence in the profession. ${ }^{29}$

Nonetheless, codes of ethics have traditionally reminded lawyers that their profession is more than just a business, and that they are quasi-public officials ("officers of the court" and "ministers of justice") who are expected to share with judges a communityminded devotion to the law. ${ }^{30}$ Would a revitalization of the more ideological qualities of codes of ethics contribute to overcoming the prevailing disillusionment with the profession? If so, could such a revitalization be achieved without diminishing the usefulness of codes of ethics to practicing lawyers confronted with immediate professional responsibility problems; without, in other words, again making them as useless as a Valentine's card to a heart surgeon in the operating room?

A review of the history of codes of ethics at a national level makes it apparent that the organized bar in both Canada and the United States has struggled almost from the outset with the issue of whether codes of ethics can and should serve both ideological and regulatory purposes.

At least at a national level, ${ }^{31}$ rules of professional conduct for lawyers are a phenomenon of the twentieth century. The American Bar Association's ("A.B.A.") Canons of Professional Ethics was first adopted in 1908. Over considerable opposition, the Canadian Bar Association ("C.B.A.") approved a set of Canons of Legal Ethics, which was based in large part on the A.B.A. model, at its fifth annual meeting, at

Kronman, supra note 4 at 5, 354.

See S. Toulmin, "Ethics and Equity: The Tyranny of Principles" (1981) 15:3 L. Soc. Gaz. 240 at 244; R.E. Loder, "Tighter Rules of Professional Conduct: Saltwater for Thirst" (1987-88) 1 Geo. J. Legal Ethics 311 at 333; R.D. Gibbons, Book Review of Professional Conduct for Canadian Lawyers by B.G. Smith (1990) 69 Can. Bar Rev. 385 at 387. Kronman, supra note 4 at 153, 374; W.W. Pue, "Becoming 'Ethical': Lawyers' Professional Ethics in Early Twentieth Century Canada" (1991) 20 Man. L.J. 227 at 227-28.

31 The American Bar Association's 1908 Canons of Professional Ethics was based in large part on the Alabama Code, which was in turn based on an influential set of lectures by Judge George Sharswood in 1854: see D. Luban, Lawyers and Justice: An Ethical Study (Princeton, New Jersey: Princeton University Press, 1988) at xxv. 
Ottawa, in 1920. Both sets of canons emphasized lawyers' public responsibilities, which were said to be greater than those of non-lawyers. These responsibilities included serving the cause of justice and securing respect for and compliance with the law, among others.

The 1920 C.B.A. Canons of Legal Ethics was adopted by law societies, just as the 1908 A.B.A. Canons of Professional Ethics was adopted by state bar associations. Both codes have been superceded twice. ${ }^{32}$

At its 1969 meeting, the Canadian Bar Association created a special committee to review the 1920 Canons and to recommend changes. As a result, a new Code of Professional Conduct was adopted by the C.B.A. in $1974 .^{33}$ The 1974 C.B.A. Code was in turn adopted, and in some cases adapted, by provincial and territorial law societies. The national executive committee of the C.B.A. resolved in 1984 to appoint a committee to review and revise the 1974 C.B.A. Code. The committee built upon the 1974 C.B.A. Code rather than starting from scratch. Two new chapters, entitled "conflicts of interest between lawyer and client" (chapter 6) and "public appearances and public statements by lawyers" (chapter 18) were added. A third chapter (chapter 13, "making legal services available"), was retitled and revised (chapter 14, "advertising, solicitation and making legal services available"), and the other chapters were revised to varying extents. ${ }^{34}$ The new code was approved in 1987.

The 1974 C.B.A. Code has been used as a basis for the rules of professional conduct of all law societies in Canada and, to a lesser extent, for the rules of the Barreau du Quebec. ${ }^{35}$ A number of law societies have adopted either the 1974 C.B.A. Code or the 1987 C.B.A. Code virtually without amendment; ${ }^{36}$ others have added to and altered the provisions of the C.B.A. Codes significantly; ${ }^{37}$ and still others have prepared their

See M.M. Orkin, Legal Ethics: A Study of Professional Conduct (Toronto: Cartwright \& Sons, 1957) at 9-10; R.D. Gibbons, supra note 29 at 385-86; C. Wolfram, Modern Legal Ethics (St. Paul, Minnesota: West, 1986) at 48; T. Ehrlich, "Introduction: Common Issues of Professional Responsibility" (1987-88) 1 Geo. J. Legal Ethics 3 at 5-6; H.S. Drinker, Legal Ethics (New York: Columbia University Press, 1953) at 21-30. Canadian Bar Association, Code of Professional Conduct (Ottawa: C.B.A., 1974) [hereinafter 1974 C.B.A. Code].

"Report of the C.B.A. Special Committee on Legal Ethics" (1993) 7:4 Law Soc. Gaz. 276; Canadian Bar Association, Code of Professional Conduct (Ottawa: C.B.A., 1987) at v (foreward) [hereinafter 1987 C.B.A. Code]; and B.G. Smith, Professional Conduct for Canadian Lawyers (Toronto: Butterworths, 1989) at 5. See Quebec's rule 1.

In Alberta, the 1974 C.B.A. Code remained in effect, together with the Law Society of Alberta's own professional conduct handbook, until the adoption of a distinctive code of professional conduct (which was also influenced by the C.B.A. Code) in January 1995; the Law Societies of Prince Edward Island, Newfoundland, the Northwest Territories and the Yukon have all adopted the 1988 C.B.A. Code with minor revisions, if any. 1987 C.B.A. Codes as a basis for their rules of professional conduct but have modified and added to the Codes significantly. 
own rules with an eye on the C.B.A. Codes, but in such a way that the final product bears almost no resemblance to either C.B.A. Code. ${ }^{38}$

In the United States, the 1908 A.B.A. canons were replaced in 1969 by the A.B.A. Model Code of Professional Responsibility. ${ }^{39}$ The Model Code was adopted, in many cases in a revised form, by almost all state bar associations. It has been revised several times since $1969 .{ }^{40}$

In 1983, the A.B.A. adopted new Model Rules of Professional Conduct. ${ }^{41}$ A majority of state bar associations have adopted a version of the Model Rules, but a significant minority are still governed by a version of the Model Code. ${ }^{42}$

An important difference between the Model Code and the Model Rules exemplifies the profession's ambivalence towards the purposes of codes of professional conduct. The Model Code consists of brief general statements of duties, which are identified as "canons": lengthy, explanatory "aspirational ethical considerations"; and black letter, mandatory "disciplinary rules." Thus an effort was made to separate matters of professional regulation and matters of ethics. The disciplinary rules are imperative statements of minimally acceptable conduct, whereas the ethical considerations are designed to point the way to morally praiseworthy conduct. ${ }^{43}$

The Model Rules eliminated this dichotomy. Like the C.B.A. code, the Model Rules consist of rules with commentaries that are intended as aids to interpretation. For the most part, the Model Rules are confined to injunctions that are appropriate and necessary for the effective regulation of the profession in the interest of protecting clients and third parties. Little effort is expended in defining or exploring the ethical or ideological dimensions of practicing law. ${ }^{44}$

Although the dual purposes of codes of professional conduct were explicitly recognized for the first time in the Model Code, they had become apparent shortly after the original canons of ethics were promulgated. The canons of ethics were soon invoked as a basis for disciplining lawyers, and since then they have been invoked to find lawyers liable for professional negligence: peculiar uses for purely ethical prescriptions. ${ }^{45}$ In MacDonald Estate, the Supreme Court of Canada held that though

ss The Law Societies of British Columbia, New Brunswick and Alberta have adopted rules of professional conduct that bear little resemblance to the C.B.A. Codes. American Bar Association, Model Code of Professional Responsibility (Chicago: A.B.A., 1969) [hereinafter Model Code].

40 See Orkin, supra note 32 at xxvii-xxviii.

4 American Bar Association, Model Rules of Professional Conduct (Chicago: A.B.A., 1983) [hereinafter Model Rules].

42 See Orkin, supra note 32 at xxvii-xxviii.

43 Ibid.; Wolfram, supra note 32 at 69; Loder, supra note 29 at 323.

4 Orkin, ibid.; and Wolfram, ibid. at 69-70.

45 See Wolfram, ibid. at 69. See also Enns v. Panju, [1978] 5 W.W.R. 244 (B.C.S.C.); Enerchem Shipmanagement Inc. v. "Coastal Canada" (The) (1988), 83 N.R. 256 (F.C.A.); Major v. Higgins (1932), 53 Que. K.B. 277 at 283; and J. Honsberger, "Legal Rules, Ethical Choices and Professional Conduct" (1987) 21:2 Law Soc. Gaz. at 113. 
rules of professional conduct are not binding on courts, ${ }^{46}$ they should nonetheless be considered important statements of public policy that express the collective views of the profession as to the appropriate standards to which lawyers should adhere. ${ }^{47}$

Canadian rules of professional conduct are patchworks that reflect both purposes. Some rules are framed in prohibitive language: "The lawyer shall not advise or represent both sides of a dispute"; 48 "The lawyer shall not stipulate for, charge, or accept any fee that is not fully disclosed, fair and reasonable." ${ }^{49}$ Others exhort lawyers to strive for exemplary ethical standards of practice: "The lawyer should encourage public respect for and try to improve the administration of justice"; ;0 "The lawyer should assist in maintaining the integrity of the profession and should participate in its activities." ${ }^{\text {51 }}$

The preface to the 1987 C.B.A. Code makes it clear that no attempt has been made in the code to define professional misconduct or conduct unbecoming a barrister and solicitor. Although the Ontario Divisional Court held that in promulgating rules of professional conduct the law society is performing a regulatory function on behalf of the legislature and government and is therefore vulnerable to scrutiny under the Canadian Charter of Rights and Freedoms, ${ }^{52}$ it would be a mistake to assimilate rules of professional conduct to a statute such as the Criminal Code. ${ }^{53}$ Not every breach of the rules of professional conduct necessarily amounts to professional misconduct or conduct unbecoming a barrister and solicitor. ${ }^{54}$ Conversely, not every act that amounts to professional misconduct is expressly proscribed by the rules. No rule specifically prohibits the misappropriation of funds held in trust for clients, for example. What constitutes professional misconduct and conduct unbecoming a barrister and solicitor is determined by discipline committees, case by case. ${ }^{s s}$

Supra note 27 at 1245 .

Ibid. at 1244, 1246. See also Essa (Township) v. Guergis; Membery v. Hill (1993), 15 O.R. (3d) 573 at 579-81 (Div. Ct.).

1987 C.B.A. Code, c. 5, rule; Law Society of Upper Canada, Professional Conduct Handbook (Toronto, Law Society of Upper Canada, 1991), r. 5 [hereinafter Ontario Handbook].

1987 C.B.A. Code, c. 11, nule; see also Ontario Handbook, r. 9 . Commentary 7 to r. 13 of the Ontario rules stipulates, anomalously, that deliberate circumvention of the Law Society's guidelines pertaining to the recruitment of articling and summer students "will be considered professional misconduct," and rule 27 provides that "sexual harassment of a colleague, of staff, of clients, or of other persons, in a professional context, is professional misconduct."

1987 C.B.A. Code, c. 13, rule; Ontario Handbook, r. 11.

1988 C.B.A. Code, c. 15, rule; Ontario Handbook, r. 13. See also S.E. Sherriff et al., "'You Can Run ... But You Can't Hide': A Guide To Understanding Lawyer Discipline In Ontario" in F. Moskoff, ed., Administrative Tribunals: A Practice Handbook for Legal Counsel (Aurora, Ontario: Canada Law Book, 1989) at 117-18; and Honsberger, supra note 45 at 118.

32 Part I of the Constitution Act, 1982, being Schedule B to the Canada Act 1982 (U.K.), 1982, c. 11.

See Klein v. Law Society (Upper Canada) (1985), 50 O.R. (2d) 118 (Div. Ct.).

Fan v. Law Society (British Columbia) (1977), 77 D.L.R. (3d) 97 (B.C.C.A.); See also Ontario Handbook, supra note 49.

Stevens v. Law Society (Upper Canada) (1979), 55 O.R. (2d) 405 at 410 (Div. Ct.). See also Sherriff et al., supra note 51 at 117-18. 
Nevertheless, codes of conduct in the United States and Canada have tended to evolve from simple statements of ideals to which members of the profession aspire to mandatory rules designed to be enforced in disciplinary proceedings. This evolutionary process is more complete in the United States. There, as mentioned above, the American Bar Association attempted to serve both ideological and regulatory functions by including in its 1969 Model Code both ethical aspirations and mandatory disciplinary rules. The A.B.A. abandoned this hybrid approach in its 1983 Model Rules, which articulate expected standards of practice in such number and detail that they are more comparable to a regulatory statute than to a traditional code of ethics. The preface to the Model Rules describes what follows as "legal rules," while urging members of the profession to look elsewhere for ethical guidance: "The Rules do not, however, exhaust the moral and ethical considerations that should inform a lawyer, for no worthwhile human activity can be completely defined by legal rules. The Rules simply provide a framework for the ethical practice of law."56

The new Alberta Code ${ }^{57}$ exemplifies an approach akin to that of the Model Rules. It consists of 129 rules that are identified as such, together with many more rules that are identified as statements of principle and commentaries, but which, pursuant to the interpretation section of the Code, are mandatory.

Should other Canadian jurisdictions adopt a similar approach? An affirmative answer is tempting, if only because the final step in an evolutionary process seems progressive, ${ }^{58}$ if not inevitable. There are, moreover, several cogent reasons for elaborating upon the still quite general admonitions of most current Canadian codes of conduct.

First, some issues of professional responsibility are sufficiently complex that it is impractical to expect individual practitioners to resolve them on the basis of general principles. Guidance from specific rules of professional conduct are a practical necessity for lawyers struggling with conflict of interest problems, for example.

Secondly, many issues of professional responsibility - conflicts of interest again spring immediately to mind - are often addressed by the courts today on disqualification motions and in solicitors' negligence actions in the conflict of interest example. It would be dangerously misleading to leave practitioners with the impression that such issues may be resolved on the basis of general principles when the applicable jurisprudence has developed relatively elaborate standards. The courts, moreover, will be less likely to defer to law societies if law societies have not articulated principles with sufficient clarity and detail to enable their members to resolve professional conduct problems consistently and responsibly. ${ }^{59}$

s6 Model Rules, supra note 41 , preface.

37 Law Society of Alberta, Code of Professional Conduct (Calgary: Law Society of Alberta, 1995).

s8 See N.J. Moore, "Elaborating Standards of Professional Conduct" (Paper presented to the Law Society of Upper Canada's Strategic Planning Conference, 25 September 1992) at 10 [unpublished]. 
Thirdly, lawyers are accustomed to applying "black-letter" rules, which are conducive to certainty in the law. The notion of determining a permissible course of conduct on the basis of aspirational ethical considerations seems foreign and equivocal. ${ }^{60}$ General ideological principles are of limited use to lawyers in answering practical questions of how they should conduct themselves in specific situations.

Finally, if the only standards articulated in a code of conduct are general, they will have to be elaborated ex post facto in contested disciplinary proceedings. Standards are thus developed incrementally through the adjudication process, case by case, like the common law. By inviting contested proceedings, codes of conduct that contain only general principles increase the strain on the limited resources of discipline committees, which already have ample work to do. More importantly, discipline committees are singularly ill-equipped to develop professional standards efficiently. Because the standards are not brought home to the practitioner in advance in the profession's code of conduct, discipline committees are likely to bend over backwards to avoid the unfairness to the practitioner of applying an exacting standard retrospectively. Particularly where both parties lead expert evidence, the less rigorous of two suggested standards is likely to be applied for disciplinary purposes, as a result of the heavy standard of proof that must be discharged by Law Society counsel in discipline proceedings. $^{61}$

There are, nevertheless, several equally cogent reasons for codes of conduct to articulate the profession's ideals and ethical aspirations.

First, as developed in some detail above, the profession over the last few years has undergone a sustained period of disillusionment both among its members and in the eyes of the public. A principal cause of disillusionment is an overemphasis by lawyers on the business dimension of the practice of law, and a corresponding belief shared by many members of the public that the profession as a whole is self-interested. Codes of ethics have traditionally served to inform the public and to remind the profession of the public service dimension of the practice of law. Codes that consist of detailed, blackletter rules that are designed to serve regulatory functions cannot help but at least dilute this public service orientation.

Secondly, the principal objective of spelling out lawyers' professional responsibilities in a comprehensive code of black-letter rules - namely, the achievement of certainty - is exceedingly difficult to achieve in practice. Certainty is generally attainable only if rules are few, simple, relatively immutable and clear in both statement and application. As Judge Richard Posner has pointed out, these are objectives that systems of legal rules rarely accomplish. ${ }^{62}$ Even where these objectives seem to have been 
achieved, there are significant differences among judges and other adjudicators in their willingness to interpret rules flexibly and to recognize exceptions freely. ${ }^{63}$

Thirdly, tighter and more comprehensive regulation can be achieved only at the price of diminished flexibility; flexibility that may be the greatest strength of selfgovernment. Unanticipated situations are more likely to be accommodated by general principles than by specific rules. Moreover, the imposition of inflexible and universal solutions is generally not the optimum approach to the resolution of complex ethical issues. ${ }^{64}$

Fourthly, an exhaustive code of black-letter rules is unlikely to attract the support of a professional consensus. Consensus is important in any system of self-government, partly because voluntary compliance is preferable to disciplinary sanctions. Rules of professional conduct adopted by the bars and law societies of the European Community in 1977 made the point in this way:

Rules of professional conduct are not designed simply to define obligations the breach of which may -involve a disciplinary sanction. A disciplinary sanction is imposed only as a last resort. It can indeed be regarded as an indication that the self-discipline of the profession has been unsuccessful. ${ }^{\text {os }}$

Finally, to spell out minimum prohibitions for disciplinary purposes entails regulating to the lowest common denominator. If the standards that are established are calibrated too high, neither widespread compliance nor rigorous enforcement is likely. Such a code will command little respect. Rules that embody minimal standards, on the other hand, almost by definition de-emphasize ethical aspirations and are certain to discourage lawyers from reaching beyond those minimums. ${ }^{66}$

\section{CONCLUSION}

An American litigation lawyer writes about his colleagues' ideological orientation to public service:

Last year several hundred lawyers at my firm devoted more than 20,000 hours of their time to public service. The work they did was extraordinary in its scope, its intensity, and its significance. We held a luncheon, and asked many of those people to describe their projects. The presentations were profoundly affecting; we heard about the Bronx and Beijing, death row and a dying river, AIDS,

63 Ibid. at $48-49$.

G See Loder, supra note 29 at 314, 323-24, 327; R.E. Loder, "Moral Scepticism and Lawyers" (1990) Utah L. Rev. 47 at 91-92.

is Consultative Committee of the Bars and Law Societies of the European Community, "The Declaration of Perugia on the Principles of Professional Conduct of the Bars and Law Societies of the European Community 16.IX.1977" (1980) 14:4 Law Soc. Gaz. at 205.

6 See Moore, supra note 58 at 13-14; Loder, supra note 29 at 311-14, 319-20, 328-32; D. Luban, "Calming the Hearse Horse: A Philosophical Research Program for Legal Ethics" (1981) 40 Md.

L. Rev. 451 at 460-61; and Toulmin, supra note 29. 
political refugees, and the homeless. For a couple of hours, we were proud of ourselves, and proud for

a profession in which this kind of work is a norm and not an exception. ${ }^{67}$

Traditional codes of ethics, with their emphasis on the collective ethical aspirations of the profession, contribute at least in some measure to this sense of pride, and to public respect for the profession. Traditional codes are at the same time insufficiently useful to practicing lawyers who encounter complex professional responsibility problems with some regularity, and who require specific guidance if the profession is to resolve such problems satisfactorily and consistently.

For the reasons developed above, the tension between the ideological and regulatory functions of codes of ethics makes the accommodation of these two commendable objectives problematic. The functions are not necessarily mutually exclusive, however. Professor Nancy Moore of Rutgers Law School has suggested a hybrid approach to the drafting of codes of ethics, an approach in which certain provisions (for instance, those dealing with conflicts of interest and confidentiality) would be elaborated on in some detail, whereas other provisions would be treated at a level of generality - a more suitable approach where, for example, there is no consensus as to what the appropriate standard should be. Thus, despite the adoption of a regulatory approach to professional responsibility problems for which lawyers require specific guidance and on which there is a consensus in the profession on the appropriate standard, the promulgation of the code of ethics would not result in the abandonment of any discussions of ethical aspirations. ${ }^{68}$

Such a compromise is unlikely to satisfy the most ardent proponents of either the regulatory or the ideological approach, but it may be the strategy that is most conducive to harmonizing the conflicting objectives.

The framers of such a code of ethics might consider the adoption of a few general guidelines:

(1) A primary purpose of a code of ethics should be the reinforcement of the public service orientation of the practice of law.

(2) At least in areas in which there is a consensus in the profession, a code of ethics should be sufficiently specific to enable practitioners to deal effectively with the immediate professional responsibility problems that they confront regularly in practice.

(3) A code of ethics should nevertheless be sufficiently flexible to be responsive to unforeseen situations.

(4) A code of ethics should not establish standards that are so stringent that voluntary compliance is discouraged. Rather, it should establish standards that 
reflect the values and practices of responsible and conscientious members of the profession.

(5) At the same time, a code of ethics should not be protective of lawyers (or, particularly in the case of confidentiality rules, of clients ${ }^{69}$ ) at the expense of the general public. Indeed (as guideline 1 provides), fostering an ethic of public service should be one of the chief objectives of such a code.

To follow these guidelines is of course to walk a tightrope between paradoxical, though perhaps not incompatible, principles. The hard part lies in the drafting. Only when the attempt is complete can we know whether the reconciliation of the ideological and regulatory functions of codes of ethics is possible. 